\title{
BIOGAS EXTRACTION FROM WASTE ORANGE PEEL BY DIGESTION PROCESS
}

\author{
N. LENIN RAKESH ${ }^{1}$, V. BALAMBICA ${ }^{2}$ \& SHANKAR KANNAN ${ }^{3}$ \\ ${ }^{I}$ Assistant Professor, Department of Mechanical Engineering, Bharath Institute of Higher Education and Research, \\ Chennai, Tamil Nadu, India \\ ${ }^{2}$ Associate Professor, Department of Mechanical Engineering, Bharath Institute of Higher Education and Research, \\ Chennai, Tamil Nadu, India \\ ${ }^{3}$ Student, Department of Mechanical Engineering, Bharath Institute of Higher Education and Research, \\ Chennai, Tamil Nadu, India
}

\begin{abstract}
In Biogas extraction from waste orange peel by digestion process the disposal methods define the fresh peels of orange for the citrus processing industry has become a major concern. Orange peels are the major solid by-product and the dried orange peels have content of protein, pectin, cellulose, and hemicellulose, those can be converted into a valuable product like methane gas by anaerobic digestion process.

Our main objective is to thoroughly inspect the prospect of handling and transformation of the waste orange peels into the valuable product like biogas. These huge amounts of orange peels are wastely disposed and disposing of them is also a very big concern for the citrus processing industry. The anaerobic digestion process is an economical process to convert the proteins, pectin, cellulose and hemicellulose which are contained in the waste orange peels into methane gas. By using this technique of extracting methane gas from orange peels by Anaerobic digestion or fermentation process, the demand for the fossil fuel can be reduced in future because it is not possible to ensure that we will have enough fossil fuel to run the engine of the vehicle as well as to produce the electricity through plants at the same time we can maintain the free pollution environment.

KEYWORDS: Hemicelluloses, Orange Peels \& Biogas
\end{abstract}

Received: Feb 28, 2019; Accepted: Mar 19, 2019; Published: Apr 17, 2019; Paper Id.: IJMPERDJUN201935

\section{INTRODUCTION}

Here our main work is to properly use the peels of orange meant for the actual manufacture of the biogas through the absorption process. Here the anaerobic digestion process can be used to recover the protein, pectin, cellulose, and hemicellulose of the waste orange peels to produce the biogas. After producing the biogas from the waste orange peels by anaerobic digestion process remaining residues can be used us the fertilizer in the field of agriculture.

The extracted methane gas can be used in the power plants to generate electric power. Since Compressed Natural Gas contains about 70 to $90 \%$ of methane gas, it can also be used in the field of an automobile to run the engine the vehicles.

\section{Properties of Biogas}

The biogas has the following properties, 
1. Lighter than the air 2. Highly combustible 3. Clean burning Efficient Abundant Odorless and invisible Noncorrosive Explosive under pressure

\section{Composition of Biogas}

Table 1: Composition of Biogas

\begin{tabular}{|c|c|c|}
\hline Component & Formula & $\begin{array}{c}\text { Concentration } \\
\text { (\% by volume) }\end{array}$ \\
\hline Methane & $\mathrm{CH}_{4}$ & $60-85$ \\
\hline Carbon dioxide & $\mathrm{CO}_{2}$ & $15-40$ \\
\hline Nitrogen & $\mathrm{N}_{2}$ & $0-5$ \\
\hline Oxygen & $\mathrm{O}_{2}$ & Less than 1 \\
\hline Hydrocarbons & $\mathrm{C}_{2} \mathrm{H}_{2 \mathrm{n}+2}$ & Less than 1 \\
\hline Water vapour & $\mathrm{H}_{2} \mathrm{O}$ & $1-5$ \\
\hline
\end{tabular}

\section{BIOGAS USES}

\section{Generation of Power}

In power generation in the course of gas turbines.

\section{Domestic Purpose}

Here mostly the biogas is supplied to homes than on generally used for cooking point.

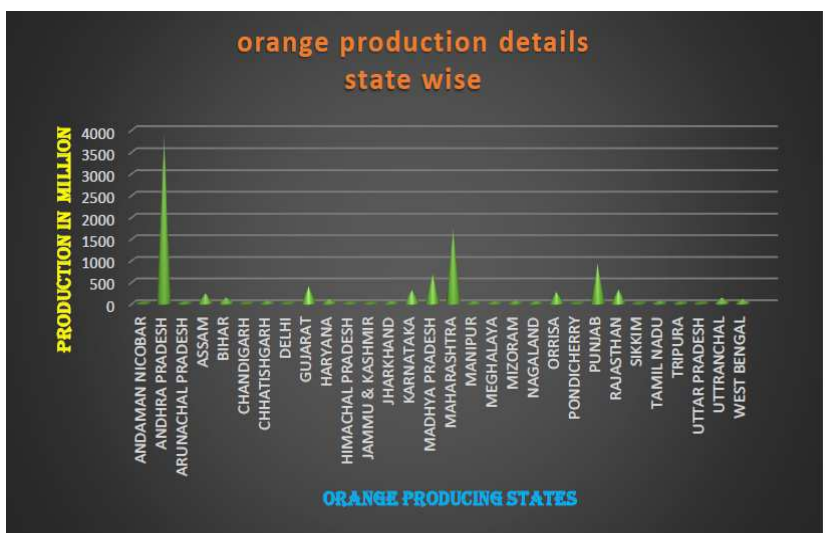

Figure 1: Production of Orange in India

\section{METHODOLOGY}

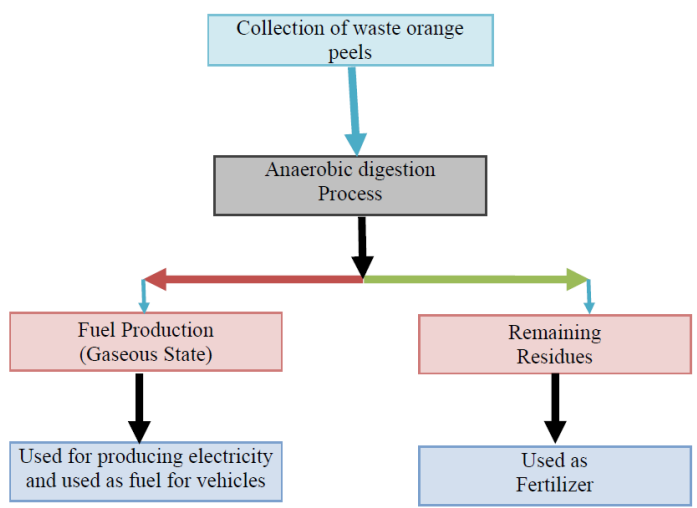

Figure 2: Block Diagram for Extracting Methane Gas from Orange Peels 


\section{Equipments and Materials Used}

\section{Equipments}

The following equipment was used in this project in order to extract the methane gas from the dried orange peel by the anaerobic digestion process.

- Incubator

- $\quad$ Digital pH meter.

- $\quad 3.200 \mathrm{ml}$ glass digester with a plastic cork.

- $\quad$ Digital weighing machine.

- $\quad$ Beaker with scale dimension.

\section{Incubator}

An incubator is electronic equipment, which is mainly used for maintaining the chemically treated samples of waste orange peel at a favorable temperature (i.e. around 55oC). The incubator, which is used in this project, is equipped with a temperature control unit in which the required temperature can be set and it is capable of maintaining the required things up to $110^{\circ} \mathrm{C}$ temperature.

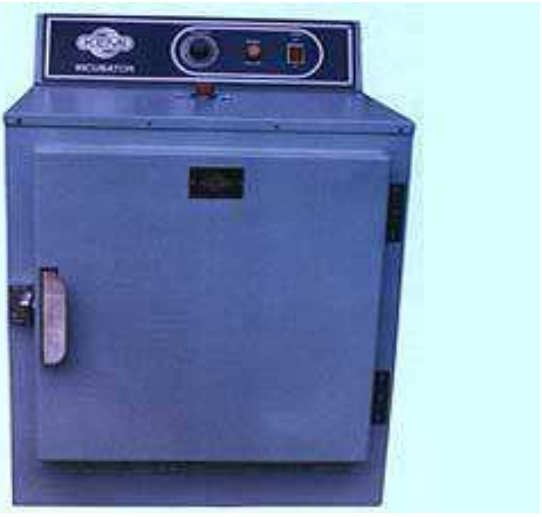

Figure 3: Incubator

This incubator is also having a temperature measuring sensor into it. Here the temperature sensor is mainly used to measure the temperature inside the incubator, so that the switch ON, OFF function of the heater in the incubator is done. It means that once the set temperature is reached inside the incubator then it will automatically switch OFF the heater and vice versa.

\section{Specification of Incubator}

Power Supply = 220 Voltage,

Single Phase: 50 HZ,

Alternate current: supply.

Temperature range: $30 \mathrm{oC}$ to $110 \mathrm{oC}$.

Accuracy: $\pm 10 \mathrm{C}$. 
Purpose: Designed to destroy bacteria, virus, and fungus which present in slurries.

\section{Materials}

The following materials are used in this project for bio-based extraction from waste orange peels.

- Waste orange peels as a bio-resource for the biogas production.

- Hexane to reduce the d-limonene concentration present in the waste orange peels.

- Lime water $(\mathrm{CaOH} 2)$ for the chemical treatment of orange peels. Lime is mainly added to carrying out the reactions faster.

- $\quad$ Enzymes for increasing the digestibility of the orange peels.

- $\quad$ Phosphate buffer $(\mathrm{NaOH}$ or $\mathrm{CO} 2)$ to adjust the $\mathrm{pH}$ of the pretreated samples of the orange peels.

some solvent often remains inside the solid after completion of the extraction process.

\section{STEPS INVOLVED IN THE PROCESS OF EXTRACTING METHANE GAS FROM PEELS}

\section{Collection and Preparation of Orange Peels}

The waste peels from the orange were collected to the required quantity. In this project, I used only 300 grams of waste orange peels to extract the methane gas from them by anaerobic digestion process. After collecting the waste orange peel, they are completely washed with the help of luck warm water (water with its temperature around $380 \mathrm{C}$ is known as luck warm water.). Then were dried, it can be done either by drying oven or usually sun-light during day time.

\section{Chemical Treatments of Orange Peel}

The orange peels were chemically treated under one condition

- Dried orange peels with various lime concentrations.

Totally ten numbers of samples in dried orange peels were prepared which are listed in the table below.

Table 2: Dried orange peels with various Concentrations of Lime and Water

\begin{tabular}{|c|c|c|c|}
\hline S.N0. & $\begin{array}{c}\text { Quantity of orange peels } \\
\text { (in gms) }\end{array}$ & $\begin{array}{c}\text { Concentration of lime } \\
\text { (in ml) }\end{array}$ & $\begin{array}{c}\text { Quantity of water } \\
\text { (in ml) }\end{array}$ \\
\hline $\mathbf{1}$ & 30 & 10 & 40 \\
\hline $\mathbf{2}$ & 30 & 9 & 41 \\
\hline $\mathbf{3}$ & 30 & 8 & 42 \\
\hline $\mathbf{4}$ & 30 & $\mathbf{7}$ & 43 \\
\hline $\mathbf{5}$ & 30 & 6 & 44 \\
\hline $\mathbf{6}$ & 30 & 5 & 45 \\
\hline $\mathbf{7}$ & 30 & 4 & 46 \\
\hline $\mathbf{8}$ & 30 & 3 & 47 \\
\hline $\mathbf{9}$ & 30 & 2 & 48 \\
\hline $\mathbf{1 0}$ & 30 & 1 & 49 \\
\hline
\end{tabular}




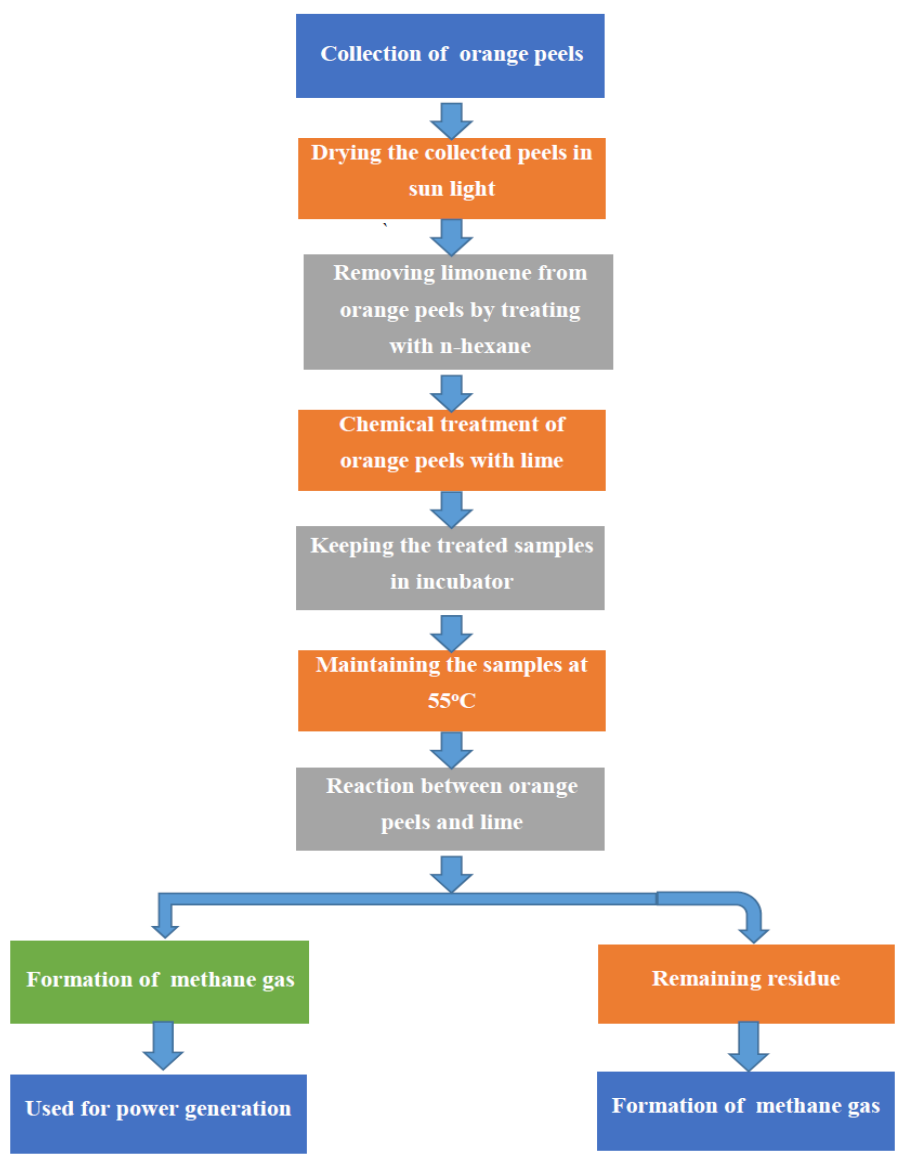

Figure 4: Flow chart

\section{MEASUREMENT TECHNIQUE}

The measurement of formed gas inside the each bottle is carried out based on the principle that, in a closed container with water and having two small holes one is at the bottom of the container and another one is at the top of the container and if the hole at the top of the container is exposed to the atmosphere, then the air will enter inside the container and the water will come out at the bottom of the container. If the hole at the top of the container is closed, then the water coming from the container at the bottom is blocked. In this project, the same foresaid technique is used to measure how much amount of gas has been formed inside each bottle.

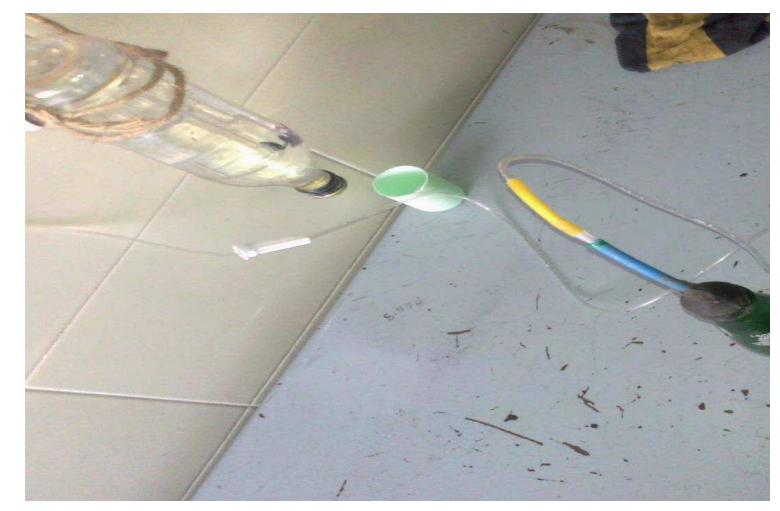

Figure 5: Picture of Measurement Technique 
A small tube with a flow control valve from the gas containing bottle is connected to the hole at the top of the container. When the valve is opened, then the water will come out from the container until the gas goes inside the container at the. Finally, the volume of water collected in the beaker is calculated then by using the relation $1 \mathrm{~m} 3=10001$ it, the total amount of gas formed (in term of $\mathrm{ml}$ ) inside the bottle is calculated.

For easy understanding,

Height of water collected in the beaker for the sample of $30 \mathrm{gms}$ peels with $(\mathrm{h})=4.5 \mathrm{~cm}=0.045 \mathrm{~m}$

$8 \mathrm{ml}$ lime, $42 \mathrm{ml}$ water

Diameter of the beaker $(\mathrm{d})=3.5 \mathrm{~cm}=0.035 \mathrm{~m}$

Volume of water collected $(\mathrm{v})=\pi / 4 * \mathrm{~d} 2 * \mathrm{~h} .=\pi / 4 * 0.0352 * 0.045$

$=0.00017325 \mathrm{~m} 2$.

(i.e. $1 \mathrm{~m} 3=1000$ lit).

$=0.17325$ lit.

$=173.25 \mathrm{ml}$.

Therefore the total amount of gas formed

For the sample, 30 grams peels under the condition of $8 \mathrm{ml}$ lime and $42 \mathrm{ml}$ water $=173.25 \mathrm{ml}$.

\section{Result of Samples of the Dried Peels with a Varying Lime Concentration}

Followings are the results which were obtained for the pre-treated samples of dried peels during 10 days of incubation of samples. When the dried peels treated with varying lime concentration, then the obtained methane yield has been shown in table 3 below. Particularly the pre-treated sample of dried peels under the condition of $16 \%$ of lime and $84 \%$ of the water has given maximum methane yield of $173.25 \mathrm{ml}$. When increasing the lime concentration above $16 \%$, then the maximum methane yield will be reduced. For instant when increasing the lime concentration from $16 \%$ to $18 \%$ in the pre-treated samples of the fully dried orange peels, then the methane has been reduced to $92.316 \mathrm{ml}$ and vice versa. Therefore the recommended lime and water concentration to get maximum methane yield is $16 \%$ of lime and $84 \%$ of water. The graph 5 below indicates the variation of methane yield when the various lime concentration is added to the pretreated samples of the dried orange peels.

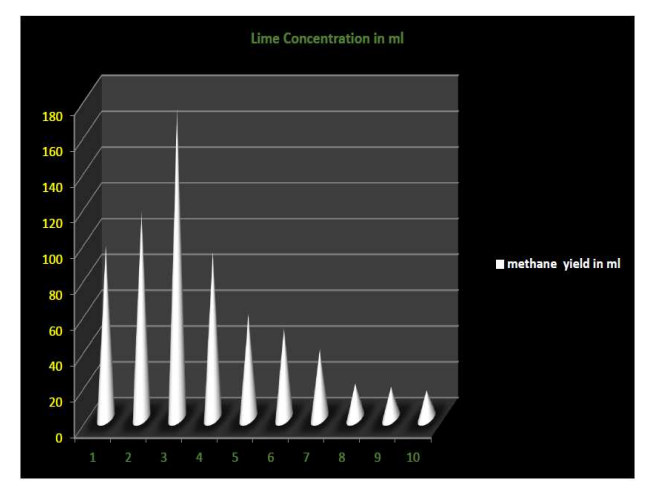

Figure 6: Pictorial Result of Samples of the Dried Orange Peels 
Table 3: Result of Samples of the Dried Orange Peels

\begin{tabular}{|c|c|c|c|c|c|c|}
\hline S.No & $\begin{array}{c}\text { Amount of } \\
\text { peels } \\
\text { (in gms) }\end{array}$ & $\begin{array}{c}\text { Quantity of } \\
\text { water } \\
\text { (in ml) }\end{array}$ & $\begin{array}{c}\text { Lime } \\
\text { concentration } \\
\text { (in ml) }\end{array}$ & $\begin{array}{c}\text { Height of } \\
\text { water } \\
\text { collected in } \\
\text { the beaker } \\
\text { (in m) }\end{array}$ & $\begin{array}{c}\text { Volume of } \\
\text { water } \\
\text { collected } \\
\text { (in } \mathbf{m}^{3} \text { ) }\end{array}$ & $\begin{array}{c}\text { Total } \\
\text { amount of } \\
\text { gas } \\
\text { (in ml) }\end{array}$ \\
\hline 1 & 30 & 40 & 10 & 0.025 & $9.61625 \mathrm{E}-05$ & 96.1625 \\
\hline 2 & 30 & 41 & 9 & 0.03 & 0.000115395 & 115.395 \\
\hline 3 & 30 & 42 & 8 & 0.045 & 0.000173093 & 173.093 \\
\hline 4 & 30 & 43 & 7 & 0.024 & 0.000092316 & 92.316 \\
\hline 5 & 30 & 44 & 6 & 0.015 & $5.76975 \mathrm{E}-05$ & 57.6975 \\
\hline 6 & 30 & 45 & 5 & 0.013 & $5.00045 \mathrm{E}-05$ & 50.0045 \\
\hline 7 & 30 & 46 & 4 & 0.01 & 0.000038465 & 38.465 \\
\hline 8 & 30 & 47 & 3 & 0.005 & $1.92325 \mathrm{E}-05$ & 19.2325 \\
\hline 9 & 30 & 48 & 2 & 0.0045 & $1.73093 \mathrm{E}-05$ & 17.3093 \\
\hline 10 & 30 & 49 & 1 & 0.004 & 0.000015386 & 15.386 \\
\hline
\end{tabular}

\section{ANAEROBIC DIGESTION PROCESS APPLICATIONS}

\section{Reducing Methane Emission from Landfills}

During employing Anaerobic Digestion Process is to recover the proteins of the dried orange peels such that the emission of pollutants like methane which affect the ocean layer is completely reduced.

\section{CONCLUSIONS}

The positive effect on enhancement of methane yield from the waste dried orange peels were obtained by anaerobic digestion process during 10 days of incubation of pre-treated samples of dried orange peels. Particularly the pretreated sample of dried orange peels under the condition of $16 \%$ of lime and $84 \%$ of the water has given maximum methane yield of $173.25 \mathrm{ml}$. when increasing the lime concentration above $16 \%$, then the maximum methane yield will be reduced. For instant when increasing the lime concentration from $16 \%$ to $18 \%$ in the pre-treated samples of dried orange peels, then the methane has been reduced to $92.316 \mathrm{ml}$ and vice versa.

Finally, I conclude to say is since every day we are consuming a huge amount of Orange as the animal feed and waste peels from them are disposed in the places like open land, lake, revere etc., they are polluting the environment and also cause some diseases to living animals. Instead of disposing of them as the waste, by using this feasible technology we can produce the bio-gas as well as we can maintain a free pollution environment. Because in the future it is not possible to say that there will be enough fuel to run the engines of the vehicles as well as to produce electricity. I hope that definitely, my project will be a source to produce bio-gas in the forthcoming years.

\section{REFERENCES}

1. Abaraham. J., 2001, Prospects and challenges of Indian meat industry. International Training Centre of Meat Technology, Republic of Botswana. Patron, Indian meat Sci.Association.

2. Abbasi, T. and Abbasi, S.A., Production of clean energy by anaerobic digestion of phytomass-New prospects for a global warming amelioration technology. Renewable and Sustainable Energy Reviews, 2010. 14(6): p. 1653-1659.

3. Anaerobic digestion of classified municipal solid wastes, seas.ucla.edu. Retrieved 24.10.07. 
4. Dean, J.R., Extraction Techniques in Analytic Sciences. 2 ed. 2010: John Wiley \& Son Inc.

5. Deublein, D. and Steinhauser, A., Biogas from waste and renewable resources: Energy supply in the future-scenarios. 2008, Wiley-VCH Weinheim. p. 7-23.

6. Okonkwo, P. C., \& Mohamed, A. M. (2014). Erosion-corrosion in oil and gas industry: a review. Int. J. Metall. Mater. Sci. Eng, 4(3), 7-28.

7. V. Balambica, T. Madhan Raj, C. Dinesh,A. Mohamed Azharudeen2 \& K. Harish.," Influence Of Stresses In A Modified NonMetallic Spur Gear Pair”., Issue 6,Dec 2018, pp 239-248.,International Journal of Mechanical and Production Engineering Research and Development (IJMPERD)., Transtellar Journal Publications.,Vol. 8.,ISSN (P): 2249-6890; ISSN (E): 2249 8001.

8. V. Balambica, R. Sachin Ritto, B. Balamuralidharan,T. Rajadurai \& A. Akthar.,” Effect Of Negative Correction Factor In Spur Gear Tooth Profile Using Fea”., Issue 2,Dec 2018, pp 1-6., International Journal of Industrial Engineering \& Technology (IJIET).,Transtellar Journal Publications.,Vol. 8., ISSN (P): 2277-4769; ISSN (E): 2278-9456.

9. Dr.V.Balambica., Vishwa Deepak,"Study and Analysis of Reducing Hand Vibration in Tractor”,,November 2017.,PP 275279.,International Journal of Pure and Applied Mathematics.,Publisher Academic Publications Ltd., Volume 116.,Special.,ISSN Print 1211-8080.,ISSN Online-1394-3395. 